Bull. Chem. Soc. Ethiop. 2017, 31(1), 93-105.

ISSN 1011-3924

(C) 2017 Chemical Society of Ethiopia and The Authors

Printed in Ethiopia

DOI: http://dx.doi.org/10.4314/bcse.v31i1.8

\title{
EXCEEDINGLY FACILE ONE-POT PROTOCOLS TO THE SYNTHESIS OF PYRIMIDO ANNULATED ANALOGUES OF CARBAZOLO CONDENSED AZEPINONES AND THEIR EVALUATION FOR ANALGESIC ACTIVITY
}

\author{
Meenakshi Agrawal ${ }^{1}$, Sonika Jain ${ }^{1}$, Swapnil Sharma ${ }^{2}$, Jaya Dwivedi ${ }^{1 *}$ and Dharma Kishore \\ ${ }^{1}$ Department of Chemistry, Banasthali University, Banasthali-304022, Rajasthan, India \\ ${ }^{2}$ Department of Pharmacy, Banasthali University, Banasthali-304022, Rajasthan, India
}

(Received August 7, 2015; revised May 8, 2017)

\begin{abstract}
Extremely simple protocols based on the reactivity of corresponding oxoketenedithioacetal (4), 2(dimethylaminomethylene) ketone (5), $\beta$-oxoenolether (6) and $\alpha, \beta$-unsaturated ketone (7) derivatives of 7 -ethyl-3, 4-dihydroazepino[3,2-b]carbazol-2,5(1H,7H)-dione (3) have been developed to provide an easy access to their pyrimido annulated analogues (8-15) of medicinal interest. The key compound 3 from which, the synthesis proceeded has been realized in two steps from the commercial 3-amino-9-ethyl carbazole (1) on its reaction in the first step with ethyl succinyl chloride followed by cyclocondensation of the resulting ester $\mathbf{2}$ with PPA. The selected synthesized compounds were screened for in-vivo analgesic activity using acetic acid induced writhing model in mice. Among them, compound $\mathbf{1 3}$ was found to be most active and found comparable to standard aspirin.
\end{abstract}

KEY WORDS: 3-Amino-9-ethyl carbazole, Oxoketnedithioacetal, Dimethyl formamide dimethyl acetal, 2-(Dimethylaminomethylene)ketone, Oxoenolether, Chalcone

\section{INTRODUCTION}

Carbazoles, benzazepines and pyrimidines exhibits a wide array of biological responses in combating a variety of body ailments by virtue of their ability to provide ligands to a number of functionally and structurally discrete receptors. Current demonstrations revealed that some of their derivatives can serve as potential agents in the treatment of cancer and AIDS has stimulated further interest in these molecules from yet another perspective.

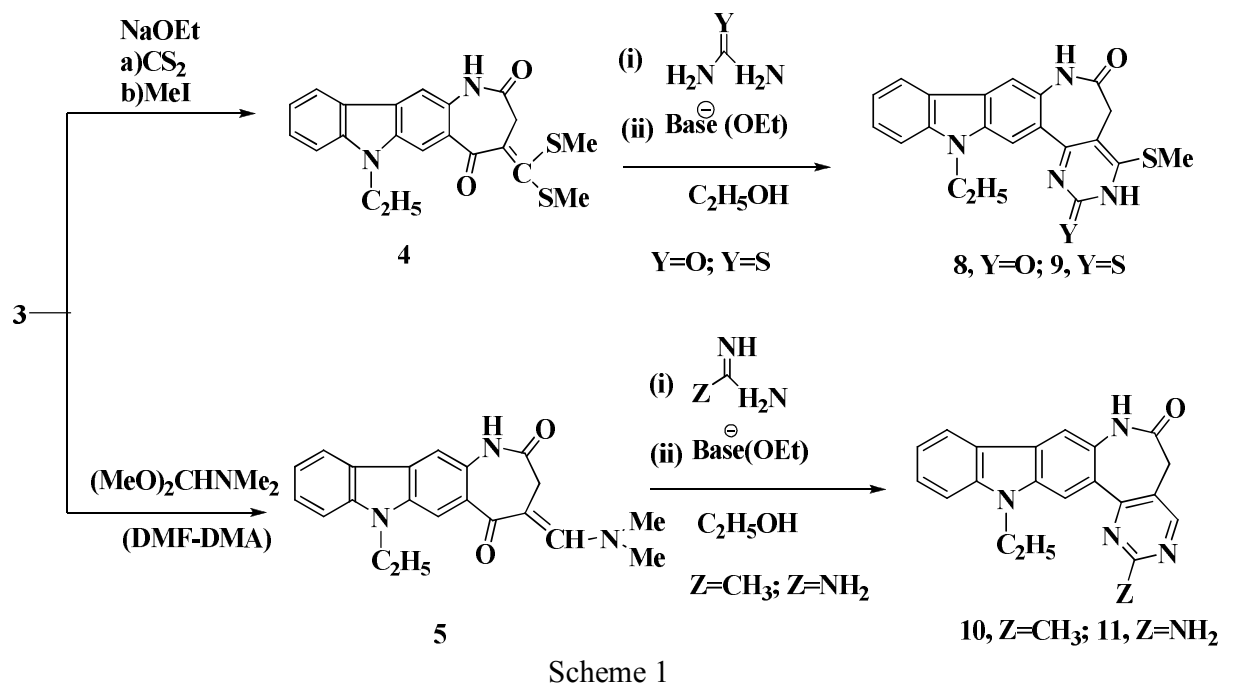

*Corresponding author. E-mail: jayadwivedi@yahoo.co.in 

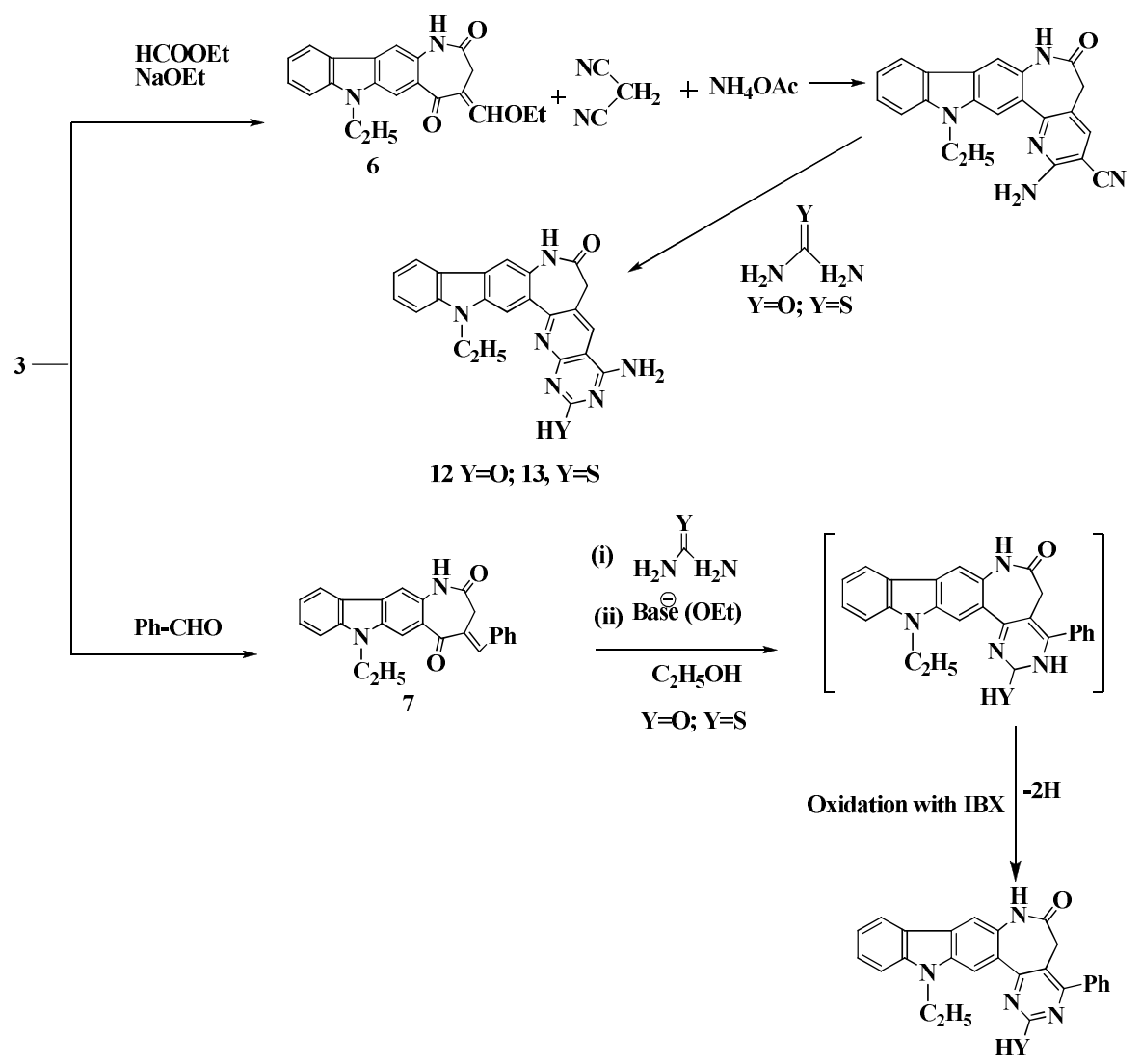

Scheme 2

$14, \mathrm{Y}=0 ; 15, \mathrm{Y}=\mathrm{S}$<smiles>CCOC(=O)C(CCC(=O)Nc1ccc2c(c1)c1ccc(Cl)cc1n2CC)C(=O)OCC</smiles>

Scheme 3

Literature is replete with examples showing that heterocycles which incorporate carbazoles [1], azepinones [2] and pyrimidines [3] in their molecular framework display wide range of bioefficacies such as anti-cancer [4], anti-leukemic [5], antiproliferative [6], anti-microbial [7], anti-viral [8], anti-malarial [9], antioxidant [10], etc. Ever since, pyrimidine derivatives have been recognized to belong to the class of 'privileged medicinal scaffolds' [11] its potential have been widely exploited in the discovery of such pyrimidine based drugs as 'Etravirine' [12] which has emerged as a highly potent anti-HIV agent, to have found the FDA approval for the treatment of AIDS. The advent of its inherent potential such as this, has led to the interest on the 
various facets of the chemistry of pyrimidine derivatives has expand exponentially, thereafter. In view of exploring, their biological potential further, we thought that it could be interesting to develop libraries ofsuch materials which contained a carbazole nucleus on one side of the azepinone framework and the bioactive pharmacophore such as the pyrimidine on its other side, on this premise, that their presence in tandem in the same molecular framework could contribute significantly to produce novel series of compounds with enhanced biological activities. In putting this concept into the action we require to develop expedient protocols to obtain the pyrimidine annulated analogues of azepino condensed carbazole derivatives 8-15 using conventional as well as microwave assisted methods. We explored the feasibility of their preparation by exploiting the synthetic potentials of oxoketenedithioacetal, 2-dimethylaminomethylene ketone, $\beta$-oxoenolether and $\alpha, \beta$-unsaturated ketone derivatives 4-7 in their synthesis through their reaction with the bidentate nucleophiles, indicated in Scheme 1 and Scheme 2. These highly reactive systems having an exceptionally high propensity in reactions towards these nucleophiles were appended on to the adjacent position, of the carbonyl function in 3 , in accordance to the procedures reported for their incorporations in the literature on related substrates. The intermediate $\mathbf{3}$ was in turn realized through the procedure outlined in Scheme 3.

\section{EXPERIMENTAL}

\section{General}

Melting points were determined in an open capillary and are uncorrected. The IR spectra were recorded on Schimadzu FTIR-8400S. ${ }^{1} \mathrm{H}-\mathrm{NMR}$ spectra were recorded in $\mathrm{CDCl}_{3}$ on Bruker DRX-300 MHz spectrometer using TMS as internal reference with their values expressed in $\delta$ ppm. Purity of all the synthesized compounds were checked by TLC on silica gel G plates in the solvent system (9:1, benzene: methanol).

Preparation of ethyl 4-(9-ethyl-9H-carbazol-3-ylamino)-4-oxobutanoate (2)

To 3-amino-9-ethyl carbazole $(\mathbf{1})(2.10 \mathrm{~g}, 0.01 \mathrm{~mol})$ in dry pyridine $(5.0 \mathrm{~mL})$ was added ethyl succinyl chloride $(1.64 \mathrm{~g}, 0.01 \mathrm{~mol})$. The mixture was refluxed for 10-15 min. Cooled reaction mixture was poured slowly with stirring to $150-200 \mathrm{~mL}$ ice cold water. The solid which settled was filtered and washed with cold water and recrystallized from hot water containing a few drops of methanol to give 2 "in yield 2.82 g" $(83 \%)$, m.p. $89-90{ }^{\circ} \mathrm{C}$.

Preparation of 7-ethyl-3,4-dihydroazepino [3,2-b] carbazol-2,5(1H, 7H)-dione (3)

To ethyl 4-(9-ethyl-9H-carbazol-3-ylamino)-4-oxobutanoate (2) (2.58 g, $0.006 \mathrm{~mol})$ PPA $20.0 \mathrm{~g}$ was added and the mixture was heated at $150-160{ }^{\circ} \mathrm{C}$ for $4 \mathrm{~h}$. (the progress of the reaction was monitored by TLC). The reaction mixture was cooled to room temperature and a concentrated solution of $\mathrm{Na}_{2} \mathrm{CO}_{3}$ in water was added to make it neutral. The product was extracted with ethyl acetate $(3 \times 10 \mathrm{~mL})$. The combined extracts were dried over anhydrous $\mathrm{Na}_{2} \mathrm{SO}_{4}$ and concentrated in vacuo. The residue was purified by column chromatography on silica gel with $\mathrm{CHCl}_{3}$ as an eluant to give 3 .

Preparation of 4-(bis(methylthio)methylene)-7-ethyl-3,4-dihydroazepino[3,2-b]carbazol2,5(1H,7H)-dione (4)

To a mixture of 7-ethyl-3,4-dihydroazepino[3,2-b]carbazol-2,5(1H,7H)-dione (3) $(1.75 \mathrm{~g}, 0.006$ $\mathrm{mol})$ and $\mathrm{CS}_{2}(1 \mathrm{~mL}, 0.006 \mathrm{~mol})$ was added a well stirred and cooled suspension of t-BuOK $(1.34 \mathrm{~g}, 0.012 \mathrm{~mol})$ in dry benzene $(4.0 \mathrm{~mL})$ and DMF $(3.0 \mathrm{~mL})$. The reaction mixture was allowed to stand at room temperature for $4 \mathrm{~h}$. Methyl iodide $(2.0 \mathrm{~mL}, 0.012 \mathrm{~mol})$ was gradually 
added with stirring and with external cooling (exothermic reaction). The reaction mixture was allowed to stand for further $4 \mathrm{~h}$. at room temperature with occasional shaking. It was then refluxed on a water bath for $3 \mathrm{~h}$. The mixture was poured on to the crushed ice and the benzene layer was collected. The aqueous portion was extracted with benzene and the combined extracts were washed, with water dried over anhydrous sodium sulfate. The solvent was removed in vacuum to give 4 .

Preparation of (E)-4-((dimethylamino) methylene-7-ethyl-3,4-dihydroazepino[3,2-b]carbazol2,5(1H,7H)-dione (5)

7-Ethyl-3,4-dihydroazepino[3,2-b]carbazol-2,5(1H,7H)-dione $3 \quad(2.92 \mathrm{~g}, \quad 0.01 \mathrm{~mol})$ was dissolved in N,N-dimethylformamide dimethylacetal $(15 \mathrm{~mL})$ and the solution was heated under reflux for $4 \mathrm{~h}$. and concentrated. The residue is triturated with hexane, filtered and washed with hexane to give 5 as a powder $(2.04 \mathrm{~g})$.

Preparation of 4-(ethoxymethylene)-7-ethyl-3,4-dihydroazepino[3,2-b]carbazole-2,5(1H,7H)dione (6)

To a suspension of sodium methoxide $(0.5 \mathrm{~g})$ in dry benzene $(25.0 \mathrm{~mL})$ at $0{ }^{\circ} \mathrm{C}$, a solution of ethyl formate $(0.74 \mathrm{~g}, 10 \mathrm{mmol})$ in dry benzene $(10.0 \mathrm{~mL})$ was added. To this mixture, 7-ethyl3,4dihydroazepino[3,2-b]carbazol-2,5(1H,7H)-dione (3) $(1.46 \mathrm{~g}, 0.005 \mathrm{~mol})$ in benzene $(10.0$ $\mathrm{mL}$ ) was then added. The mixture was stirred for $4 \mathrm{~h}$. at room temperature and allowed to stand overnight. It is then diluted with cold water, acidified with dil. $\mathrm{HCl}$ and extracted with ether. The solvent was evaporated and the resulting compound was recrystallized from ethanol to give the pure product $\mathbf{6},(1.08 \mathrm{~g})$.

Preparation of (Z)-4-benzylidene-7-ethyl-3,4-dihydroazepino[3,2-b]carbazole-2,5(1H,7H)dione (7)

A mixture of 7-ethyl-3,4-dihydroazepino[3,2-b] carbazol-2,5(1H,7H)-dione (3) $(2.92 \mathrm{~g}, 0.01$ $\mathrm{mol})$, benzaldehyde $(1.06 \mathrm{~g}, 0.01 \mathrm{~mol})$ and fused sodium acetate $(1.8 \mathrm{~g}, 0.015 \mathrm{~mol})$ in glacial acetic acid $(10 \mathrm{~mL})$ was refluxed for $5 \mathrm{~h}$. The reaction mixture was cooled in ice water. The crude solid was filtered, washed with water and recrystallized from aqueous ethanol to give 7 , (2.30 g) m.p. $72-73{ }^{\circ} \mathrm{C}$.

Preparation of 2-hydroxy-4-(methylthio)-5,7-dihydro-2H-N-ethylcarbazolo[b]pyrimido[4,5d] azepin-6(3H)-one (8)

To a mixture of urea $(0.12 \mathrm{~g}, 0.002 \mathrm{~mol})$, sodium ethoxide $(0.14 \mathrm{~g}, 0.002 \mathrm{~mol})$ and ethanol $(25.0$ $\mathrm{mL}$ ) was added 4-(bis(methylthio)methylene)-7-ethyl-3,4-dihydroazepino[3,2-b]carbazol2,5(1H,7H)-dione $(4)(0.79 \mathrm{~g}, 0.002 \mathrm{~mol})$. The reaction mixture was refluxed for $13-14 \mathrm{~h}$. The solvent was removed by distillation and the residue was treated with glacial acetic acid (4-5 mL) (just enough to dissolve sodium salt of pyrimidine) and refluxed for $15 \mathrm{~min}$. It was poured on crushed ice and the precipitated of $\mathbf{8}$ was purified by crystallization with chloroform $(450 \mathrm{mg})$, m.p. $190-191{ }^{\circ} \mathrm{C}$.

\section{Solution phase microwave assisted method for the preparation of (8)}

Urea $(0.12 \mathrm{~g}, \quad 0.002 \mathrm{~mol})$, sodium ethoxide $(0.14 \mathrm{~g}, \quad 0.002 \mathrm{~mol})$ and 4-(bis (methylthio)methylene)-7-ethyl-3,4-dihydroazepino[3,2-b]carbazole-2,5(1H,7H)-dione (4) $(0.79$ $\mathrm{g}, 0.002 \mathrm{~mol})$ was taken in ethanol $(5.0 \mathrm{~mL})$. It was placed in a $100 \mathrm{~mL}$ borosil flask fitted with a funnel as a loose top. The reaction mixture was subjected to microwave irradiation at $180 \mathrm{~W}$ microwave power for $2 \mathrm{~min}$ followed by $360 \mathrm{~W}$ for $5 \mathrm{~min}$ and then at $720 \mathrm{~W}$ for $2 \mathrm{~min}$ (a short 
interval of $1 \mathrm{~min}$ to avoid the excessive evaporation of solvents). Solid was treated with glacial acetic acid (4-5 mL) (just enough to dissolve sodium salt of pyrimidine) and refluxed to microwave irradiation at $180 \mathrm{~W}$ microwave power for $1 \mathrm{~min}$ and $360 \mathrm{~W}$ for $2 \mathrm{~min}$. The overheating of the solution was avoided. The reaction mixture was poured on crushed ice and precipitated 8 was purified by crystallization with chloroform $(350 \mathrm{mg})$.

Preparation of 2-mercapto-4-(methylthio)-5,7-dihydro-2H-N-ethyl carbazolo[b]pyrimido [4,5d] azepin-6(3H)-one (9)

To a mixture of thiourea $(0.152 \mathrm{~g}, 0.002 \mathrm{~mol})$, sodium ethoxide $(0.14 \mathrm{~g}, 0.002 \mathrm{~mol})$ in ethanol $(25.0 \mathrm{~mL})$ was added 4-(bis(methylthio)methylene)-7-ethyl-3,4-dihydroazepino[3,2b] carbazole-2,5(1H,7H)-dione $(4)(0.79 \mathrm{~g}, 0.002 \mathrm{~mol})$. The reaction mixture was refluxed for 13-14 $\mathrm{h}$. The solvent was removed by distillation. The residue was treated with glacial acetic acid (4-5 mL) (just enough to dissolve sodium salt of pyrimidine) and refluxed for $15 \mathrm{~min}$. The reaction mixture was poured on crushed ice and precipitated 9 was purified by crystallization with chloroform (460 mg).

Solution phase microwave assisted method for the preparation of (9)

Equimolar quantities of thiourea $(0.152 \mathrm{~g}, 0.002 \mathrm{~mol})$, sodium ethoxide $(0.14 \mathrm{~g}, 0.002 \mathrm{~mol})$ and 4-(bis(methylthio)methylene)-7-ethyl-3,4-dihydroazepino[3,2-b]carbazol-2,5(1H,7H)-dione (4) $(0.79 \mathrm{~g}, 0.002 \mathrm{~mol})$ were taken in ethanol $(5.0 \mathrm{~mL})$ and was placed in a $100 \mathrm{~mL}$ borosil flask fitted with a funnel as a loose top. The reaction mixture was subjected to microwave irradiation at $180 \mathrm{~W}$ microwave power for $2 \mathrm{~min}, 360 \mathrm{~W}$ for $5 \mathrm{~min}$ and then at $720 \mathrm{~W}$ for $2 \mathrm{~min}$ (with short interval of $1 \mathrm{~min}$. to avoid the excessive evaporation of solvents). The residue was treated with glacial acetic acid (4-5 mL) (just enough to dissolve sodium salt of pyrimidine) and refluxed in a microwave at $180 \mathrm{~W}$ microwave power for $1 \mathrm{~min}$. and $360 \mathrm{~W}$ for $2 \mathrm{~min}$. The overheating of the solution was avoided. The reaction mixture was poured on crushed ice and precipitated 9 was purified by crystallization with chloroform (400 mg), m.p. $210-212^{\circ} \mathrm{C}$.

Preparation of 2-methyl-5H-N-ethyl carbazolo[b]pyrimido[4,5-d]azepin-6(7H)-one (10)

To a solution of (E)-4-((dimethylamino)methylene-7-ethyl-3,4-dihydroazepino[3,2-b]carbazole2,5(1H,7H)-dione (5) $(0.115 \mathrm{~g}, 333 \mathrm{mmol})$ in ethanol $(10.0 \mathrm{~mL})$ was added acetamidine hydrochloride $(0.158 \mathrm{mg}, 1.67 \mathrm{mmol})$ and $\mathrm{Et}_{3} \mathrm{~N}(2.35 \mathrm{~g}, 1.69 \mathrm{mmol})$. The solution was heated under reflux for $42 \mathrm{~h}$ and concentrated. The residue was extracted with AcOEt and washed with water. The organic layer was dried over anhydrous $\mathrm{MgSO}_{4}$. The residue was purified by column chromatography on silica gel and eluted with hexane: AcOEt (1:2) to give brown crystals of 10 (68 mg).

Solution phase microwave assisted method for the preparation of (10)

(E)-4-((Dimethylamino)methylene-7-ethyl-3,4-dihydroazepino[3,2-b]carbazole-2,5(1H,7H)-

dione $(5)(0.115 \mathrm{~g}, 333 \mathrm{mmol})$ in ethanol $(10.0 \mathrm{~mL})$ was added acetamidine hydrochloride $(0.158 \mathrm{~g}, 1.67 \mathrm{mmol})$ and $\mathrm{Et}_{3} \mathrm{~N}(2.35 \mathrm{~g}, 1.69 \mathrm{mmol})$. The mixture was placed in a $100 \mathrm{~mL}$ borosil flask fitted with a funnel as a loose top. The reaction mixture was subjected to microwave irradiation at $360 \mathrm{~W}$ for $6 \mathrm{~min}$ and then at $720 \mathrm{~W}$ for $3 \mathrm{~min}$ (with short interval of 1 min to avoid the excessive evaporation of solvents). The residue was extracted with AcOEt and washed with water. The organic layer was dried over anhydrous $\mathrm{MgSO}_{4}$. The residue was purified by column chromatography on silica gel and eluted with hexane: AcOEt (1:2) to give brown crystals of $\mathbf{1 0}(72 \mathrm{mg})$. 
Preparation of 2-amino-5H-N-ethyl carbazolo[b]pyrimido[4,5-d] azepin-6(7H)-one (11)

To a solution of (E)-4-((dimethylamino)methylene-7-ethyl-3,4-dihydroazepino[3,2-b]carbazol$2,5(1 \mathrm{H}, 7 \mathrm{H})$-dione $(5)(0.115 \mathrm{~g}, 333 \mathrm{mmol})$ in ethanol $(25.0 \mathrm{~mL})$ were added guanidine carbonate (1.5 g., $66.5 \mathrm{mmol})$ and sodium acetate $(2.6 \mathrm{~g}, 0.04 \mathrm{~mole})$. The mixture was heated under reflux for $56 \mathrm{~h}$. The reaction mixture was filtered insoluble material was extracted with chloroform and washed with water. The organic layer was dried over anhydrous $\mathrm{MgSO}_{4}$ and evaporated to give 11, $(70 \mathrm{mg})$, m.p. $165-167^{\circ} \mathrm{C}$.

Solution phase microwave assisted method for the preparation of (11)

Solution of (E)-4-((dimethylamino)methylene-7-ethyl-3,4-dihydroazepino[3,2-b]carbazol$2,5(1 \mathrm{H}, 7 \mathrm{H})$-dione $(5)(0.115 \mathrm{~g}, 0.333 \mathrm{mmol})$ in ethanol was added guanidine carbonate $(1.5 \mathrm{~g}$, $66.5 \mathrm{mmol}$ ) and sodium acetate (2.6 g, 0.04 mole). The mixture was placed in a $100 \mathrm{~mL}$ borosil flask fitted with a funnel as a loose top. The reaction mixture is subjected to microwave irradiation at $360 \mathrm{~W}$ for $6 \mathrm{~min}$ and then at $720 \mathrm{~W}$ for $3 \mathrm{~min}$ (with short interval of $1 \mathrm{~min}$ to avoid the excessive evaporation of solvents). The reaction mixture was filtered; insoluble material was extracted with chloroform and washed with water. The organic layer was dried over anhydrous $\mathrm{MgSO}_{4}$ and evaporated to give $\mathbf{1 1}(75 \mathrm{mg})$.

Preparation of 4-amino-7H-N-ethylcarbazolo[b]pyridopyrimidin-2-ol [2, 3-d] azepine-9(10H)one (12)

The solution of 7-ethyl-4-(hydroxymethylene)-3,4-dihyroazepino[3,2-b]carbazol-2,5(1H,7H)dione $(6)(1.74 \mathrm{~g}, 0.005 \mathrm{~mol})$, malononitrile $(0.33 \mathrm{~g}, 0.005 \mathrm{~mol})$ and ammonium acetate $(0.04$ $\mathrm{mol})$ in ethanol $(10 \mathrm{ml})$ was refluxed on a water bath for $20-22 \mathrm{~h}$. The reaction mixture was cooled and poured on the crushed ice with constant stirring. A solid mass obtained was washed with water and ethanol and then the mixture of this solid mass $(0.01 \mathrm{~mol})$ and urea $(0.02 \mathrm{~mol})$ was heated on an oil bath at $180{ }^{\circ} \mathrm{C}$ and finally the mixture was heated at $220{ }^{\circ} \mathrm{C}$ for $2 \mathrm{~h}$. On cooling the product solidified, which was recrystallized from DMF-EtOH mixture (1:2) to give $12(1.20 \mathrm{~g})$.

Solution phase microwave assisted method for the preparation of (12)

The solution of 7-ethyl-4-(hydroxymethylene)-3,4-dihyroazepino[3,2-b]carbazol-2,5(1H,7H)dione (6) (1.74 g, $0.005 \mathrm{~mol})$, malononitrile $(0.33 \mathrm{~g}, 0.005 \mathrm{~mol})$ and ammonium acetate $(0.04$ $\mathrm{mol})$ in ethanol $(10 \mathrm{~mL})$ was placed in a $100 \mathrm{~mL}$ borosil flask fitted with a funnel as a loose top. The reaction mixture was subjected to microwave irradiation at $180 \mathrm{~W}$ microwave power for 3 min, $360 \mathrm{~W}$ for $4 \mathrm{~min}$ and then at $720 \mathrm{~W}$ for $3 \mathrm{~min}$ (with a short interval of 1 min to avoid the excessive evaporation of solvents). The reaction mixture was cooled and poured on the crushed ice with constant stirring. The solid mass thus obtained was washed with water and ethanol and then to this mixture of this solid mass $(0.01 \mathrm{~mol})$ and urea $(0.02 \mathrm{~mol})$ and heated in a microwave at $180 \mathrm{~W}$ microwave power for $1 \mathrm{~min}, 360 \mathrm{~W}$ for $2 \mathrm{~min}$ and then at $720 \mathrm{~W}$ for $1 \mathrm{~min}$ (with short interval of $1 \mathrm{~min}$. to avoid the excessive evaporation of solvents). On cooling the product solidified, which was recrystallized from DMF-EtOH mixture (1:2) to give 12 (1.08 g).

Preparation of 4-amino-7H-N-ethylcarbazolo[b]pyridopyrimidin-2-thiol[2,3-d] azepine-9 (10H)-one (13)

The mixture of 7-ethyl-4-(hydroxymethylene)-3,4-dihyroazepino[3,2-b]carbazol-2,5(1H,7H)dione (6) (1.74 g, $0.005 \mathrm{~mol})$, malononitrile $(0.33 \mathrm{~g}, 0.005 \mathrm{~mol})$ and ammonium acetate $(0.04$ $\mathrm{mol})$ in ethanol $(10 \mathrm{~mL})$ was refluxed on a water bath for $20-22 \mathrm{~h}$. The reaction mixture was cooled and poured on the crushed ice with constant stirring. The solid mass obtained was

Bull. Chem. Soc. Ethiop. 2017, 31(1) 
washed with water and ethanol and then to this mixture of this solid mass $(0.01 \mathrm{~mol})$ was added thiourea $(0.02 \mathrm{~mol})$ and heated on an oil bath at $180{ }^{\circ} \mathrm{C}$ and finally the mixture was heated at $220{ }^{\circ} \mathrm{C}$ for $2 \mathrm{~h}$. On cooling the product solidified, which was recrystallized from DMF-EtOH mixture (1:2) to give $\mathbf{1 3}(1.14 \mathrm{~g})$.

Solution phase microwave assisted method for the preparation of (13)

The mixture of 7-ethyl-4-(hydroxymethylene)-3,4-dihyroazepino[3,2-b]carbazole-2,5(1H,7H)dione (6) (1.74 g, $0.005 \mathrm{~mol})$, malononitrile $(0.33 \mathrm{~g}, 0.005 \mathrm{~mol})$ and ammonium acetate $(0.04$ $\mathrm{mol})$ in ethanol $(10 \mathrm{~mL})$ was placed in a $100 \mathrm{~mL}$ borosil flask fitted with a funnel as a loose top. The reaction mixture was subjected to microwave irradiation at $180 \mathrm{~W}$ microwave power for 3 min., $360 \mathrm{~W}$ for $4 \mathrm{~min}$ and then at $720 \mathrm{~W}$ for $3 \mathrm{~min}$ (with short interval of $1 \mathrm{~min}$ to avoid the excessive evaporation of solvents). The reaction mixture was cooled and poured on the crushed ice with constant stirring. The solid mass thus obtained was washed with water and ethanol and then to this mixture was added thiourea $(0.02 \mathrm{~mol})$ and heated to microwave at $180 \mathrm{~W}$ microwave power for $1 \mathrm{~min}$., $360 \mathrm{~W}$ for $2 \mathrm{~min}$ and then at $720 \mathrm{~W}$ for $1 \mathrm{~min}$ (with a short interval of $1 \mathrm{~min}$ to avoid the excessive evaporation of solvents). On cooling the product solidified, which was recrystallized from DMF-EtOH mixture (1:2) to give 13 (1.06 g).

Preparation of 2-hydroxy-4-phenyl-5,7-dihydro-2H-N-ethylcarbazolo[b]pyrimido[4,5-d]azepin6(3H)-one (14)

The mixture of (Z)-4-benzylidene-7-ethyl-3,4-dihydroazepino[3,2-b]carbazol-2,5(1H,7H)-dione (7) $(0.380 \mathrm{~g}, 0.001 \mathrm{~mol})$, urea $(0.11 \mathrm{~g}, 0.001 \mathrm{~mol})$ and $\mathrm{NaOH}(0.1 \mathrm{~g})$ in $25 \mathrm{~mL}$ of $80 \%$ dilute ethanol was refluxed for $1.5 \mathrm{~h}$. The reaction mixture was concentrated, and cooled, the precipitate obtained was filtered off and recrystallized from DMF/water to give $14(260 \mathrm{mg})$.

Preparation of 2-mercapto-4-phenyl-5,7-dihydro-2H-N-ethyl carbazolo[b]pyrimido[4,5d] azepin-6(3H)-one (15)

The mixture of (Z)-4-benzylidene-7-ethyl-3,4-dihydroazepino[3,2-b]carbazole-2,5(1H,7H)dione (7) $(0.380 \mathrm{~g}, 0.001 \mathrm{~mol})$, thiourea $(0.01 \mathrm{~g}, 0.001 \mathrm{~mol})$ and $\mathrm{NaOH}(0.1 \mathrm{~g})$ in $25 \mathrm{~mL}$ of $80 \%$ dilute ethanol was refluxed for $1.5 \mathrm{~h}$. The reaction mixture was concentrated, cooled and the precipitate obtained was filtered off and recrystallized from DMF/water to give $\mathbf{1 5}(250 \mathrm{mg})$.

\section{Evaluation of analgesic activity}

Acute toxicity studies were carried out in mice in accordance to OECD-420 guidelines [13]. Albino mice (20-25 g) either sex were divided into six groups of containing six animals each. Animals were starved for $24 \mathrm{~h}$ with water ad libitum prior to test. On the day of the experiment, animals were administered with different test compounds to different groups in graded doses of $10-1000 \mathrm{mg} / \mathrm{kg}$ body weight orally. The animals were then observed continuously for $3 \mathrm{~h}$ for general behavioral, neurological, autonomic profiles and then every $30 \mathrm{~min}$ for next $3 \mathrm{~h}$ and also for incidences of mortality if any.

Peripheral analgesic activity - acetic acid induced writhing test in mice

Mice were divided into six groups containing six each mice. The control group received normal saline $(2 \mathrm{~mL} / \mathrm{kg}$, I.P.). The test groups were treated with compounds $(10 \mathrm{mg} / \mathrm{kg}$ I.P.) while the second group received aspirin at the dose of $10 \mathrm{mg} / \mathrm{kg}$ I.P. After $30 \mathrm{~min}$ of compound administration, the mice were challenged with $0.6 \%$ acetic acid intraperitoneally $\left(10 \mathrm{~mL} \mathrm{~kg}^{-1}\right)$ [14]. Five minutes after acetic acid injection, mice were placed in individual cage and the 
number of abdominal contractions was counted for each mouse for a period of 10 min after 5 min latency, and the percentage inhibition of writhing was calculated.

The percentage inhibition was calculated by using the formula:

Percentage inhibition $=\left(\mathrm{N}_{\mathrm{C}}-\mathrm{N}_{\mathrm{T}} / \mathrm{N}_{\mathrm{C}}\right) \times 100$

Where $\mathrm{N}_{T}$ is average number of writhing in treated group and $\mathrm{N}_{C}$ is average number of writhing in control group.

\section{RESULTS AND DISCUSSION}

As a part of an ongoing endeavour to develop novel heterocyclic scaffolds of anticipated biological activity [15-17] from easily accessible starting materials, we report herein in this communication, the preliminary results of our study on the synthesis of pyrimidine annulated analogues of carbazolo fused azepinones (8-15) from 7-ethyl-3,4-dihydroazepino[3,2-b] carbazol-2,5(1H,7H)-dione (3) [18]. A perusal of literature on the preparation of oxoketenedithioacetals, 2-(dimethylaminomethylene) ketones, oxoenolethers and $\alpha, \beta$ unsaturated ketones (chalcones), demonstrated that these were readily available from the base catalyzed condensation of carbonyl species containing an active methylene group with (i) $\mathrm{CS}_{2}+$ MeI (ii) DMF-DMA (iii) HCOOEt and (IV) $\mathrm{C}_{6} \mathrm{H}_{5} \mathrm{CHO}$ respectively. Application of this strategy on 3 afforded the intermediates 4-7 in moderate to good yield. The versatility of these novel precursors in heteroannulations of 3 was examined by allowing 4-7 derivatives to react with urea, thiourea, acetamidine and guanidine, which resulted the desired pyrimidine annulated analogues (8-15) in acceptable yields. Compound 3 was in turn realized from the commercial 3amino-9-ethyl carbazole (1) on its reaction with ethyl succinyl chloride under the conditions of Friedel-Crafts acylation, followed by cyclocondensation of the resulting intermediate with PPA. The physical analytical and spectral data of the compounds are given in Table 1 and 2. All the synthesized compounds gave satisfactory results for elemental analysis. IR and ${ }^{1} \mathrm{H}-\mathrm{NMR}$ spectral data which were found to be consistent to the structures assigned to these molecules.

Physical, analtical and spectral data of compounds 3-15

3. Yield, 59\%, m.p. $158-160{ }^{\circ} \mathrm{C}$. IR ( $\left.\mathrm{KBr}\right) \mathrm{cm}^{-1} 3340$ [NH str], 2946 [C-H str ArH], 1704 [C=O str], 1712 [C=O str], 1458 [C-H str $\mathrm{CH}_{3}$ ], 1072 [C-N str]. ${ }^{1} \mathrm{H}-\mathrm{NMR}\left(\mathrm{CDCl}_{3}\right) \delta 8.0(1 \mathrm{H}, \mathrm{s}, \mathrm{NH})$, $7.78(1 \mathrm{H}, \mathrm{s}, \mathrm{CH}), 7.63(1 \mathrm{H}, \mathrm{s}, \mathrm{CH}), 7.55(1 \mathrm{H}, \mathrm{d}, \mathrm{CH}, \mathrm{J}=6.2), 7.40(1 \mathrm{H}, \mathrm{d}, \mathrm{CH}, \mathrm{J}=6.4), 7.08$ $(1 \mathrm{H}, \mathrm{t}, \mathrm{CH}, \mathrm{J}=6.5,6.1), 7.00(1 \mathrm{H}, \mathrm{t}, \mathrm{CH}, \mathrm{J}=6.4,6.1), 3.89\left(2 \mathrm{H}, \mathrm{q}, \mathrm{CH}_{2}\right), 2.93\left(2 \mathrm{H}, \mathrm{t}, \mathrm{CH}_{2}, \mathrm{~J}=\right.$ 7.1, 7.0), $2.42\left(2 \mathrm{H}, \mathrm{t}, \mathrm{CH}_{2} \mathrm{~J}=8.3,8.2\right), 1.51\left(3 \mathrm{H}, \mathrm{t}, \mathrm{CH}_{3} \mathrm{~J}=7.3,7.5\right) \cdot{ }^{13} \mathrm{C}-\mathrm{NMR}\left(\mathrm{CDCl}_{3}\right) \delta 14.4$, $27.5,34,38,109,110,111,112,118,119,120,122,125,128,131,134,171,200 . \mathrm{MS}:[\mathrm{m} / \mathrm{z}]$ $292(19 \%, M)$. Anal. calcd./found for $\mathrm{C}_{18} \mathrm{H}_{16} \mathrm{~N}_{2} \mathrm{O}_{2}$ : C, 73.95/73.93; H, 5.52/5.49; N, 9.58/9.62.

4. Yield, 47\%, m.p. $74-75^{\circ} \mathrm{C}$. IR $(\mathrm{KBr}) \mathrm{cm}^{-1} 1690$ [C=O str], 1705 [C=O str], 1020 [C-N str], 680 [C-S str]. ${ }^{1} \mathrm{H}-\mathrm{NMR}\left(\mathrm{CDCl}_{3}\right) \delta, 8.0(1 \mathrm{H}, \mathrm{s}, \mathrm{NH}), 7.74(1 \mathrm{H}, \mathrm{s}, \mathrm{CH}), 7.70(1 \mathrm{H}, \mathrm{s}, \mathrm{CH}), 7.55$ $(1 \mathrm{H}, \mathrm{d}, \mathrm{CH}, \mathrm{J}=6.1), 7.40(1 \mathrm{H}, \mathrm{d}, \mathrm{CH}, \mathrm{J}=6.5), 7.08(1 \mathrm{H}, \mathrm{t}, \mathrm{CH}, \mathrm{J}=6.2,6.3), 7.00(1 \mathrm{H}, \mathrm{t}, \mathrm{CH}, \mathrm{J}=$ 6.7, 6.5), $3.89\left(2 \mathrm{H}, \mathrm{q}, \mathrm{CH}_{2}\right), 2.90\left(2 \mathrm{H}, \mathrm{s}, \mathrm{CH}_{2}\right), 2.25\left(3 \mathrm{H}, \mathrm{s}, \mathrm{CH}_{3}\right), 3.25\left(3 \mathrm{H}, \mathrm{s}, \mathrm{CH}_{3}\right), 1.51(3 \mathrm{H}, \mathrm{t}$, $\left.\mathrm{CH}_{3}, \mathrm{~J}=7.5,7.6\right) .{ }^{13} \mathrm{C}-\mathrm{NMR}\left(\mathrm{CDCl}_{3}\right) \delta 14.6,18,18.5,21,37,103,109.5,110.4,111,112$, $119.8,120.5,121,123,125,126,135,155,165,187,193 \mathrm{MS}:[\mathrm{m} / \mathrm{z}] 396(25 \%, \mathrm{M})$. Anal. calcd./found for $\mathrm{C}_{21} \mathrm{H}_{20} \mathrm{~N}_{2} \mathrm{O}_{2} \mathrm{~S}_{2}$ : C, 63.61/63.63; H, 5.08/5.05; N, 7.06/7.13; S, 16.17/16.25.

5. Yield, 58\%, m.p. $80-81^{\circ} \mathrm{C}$. IR (KBr) cm $\mathrm{cm}^{-1} 1680$ [C=O str], 1710 [C=O str], 1050 [C-N str], 815 [o-monosub]. ${ }^{1} \mathrm{H}-\mathrm{NMR}\left(\mathrm{CDCl}_{3}\right) \delta, 8.0(1 \mathrm{H}, \mathrm{s}, \mathrm{NH}), 7.74(1 \mathrm{H}, \mathrm{s}, \mathrm{CH}), 7.70(1 \mathrm{H}, \mathrm{s}, \mathrm{CH}), 7.55$ $(1 \mathrm{H}, \mathrm{d}, \mathrm{CH}, \mathrm{J}=6.1), 7.40(1 \mathrm{H}, \mathrm{d}, \mathrm{CH}, \mathrm{J}=6.2), 7.26(1 \mathrm{H}, \mathrm{s}, \mathrm{CH}), 7.08(1 \mathrm{H}, \mathrm{t}, \mathrm{CH}, \mathrm{J}=6.8,6.7)$, $7.00(1 \mathrm{H}, \mathrm{t}, \mathrm{CH}, \mathrm{J}=6.5,6.3), 3.89\left(2 \mathrm{H}, \mathrm{q}, \mathrm{CH}_{2}\right), 2.90\left(2 \mathrm{H}, \mathrm{s}, \mathrm{CH}_{2}\right), 2.47\left(6 \mathrm{H}, \mathrm{s}, \mathrm{CH}_{3}\right), 1.51(3 \mathrm{H}$, 
t, $\left.\mathrm{CH}_{3}, \mathrm{~J}=7.5,7.6\right) .{ }^{13} \mathrm{C}-\mathrm{NMR}\left(\mathrm{CDCl}_{3}\right) \delta 14.6,27,38,43.5,44.6,103,109,110,111,111.7$, $112,119,121,125,125.7,126,135.2,136,149,168,187 . \mathrm{MS}:[\mathrm{m} / \mathrm{z}] 347$ (22\%, M). Anal. calcd./found for $\mathrm{C}_{21} \mathrm{H}_{21} \mathrm{~N}_{3} \mathrm{O}_{2}$ : C, 72.60/72.62; H, 6.09/6.03; N, 12.10/12.08.

6. Yield, $62 \%$, m.p. $90-91{ }^{\circ} \mathrm{C}$. IR $(\mathrm{KBr}) \mathrm{cm}^{-1} 1685[\mathrm{C}=\mathrm{O}$ str], $1705[\mathrm{C}=\mathrm{O}$ str], $1480[\mathrm{C}=\mathrm{C}$ str $\mathrm{ArH}$ ], 1120 [C-N str], 810 [o-monosub]. ${ }^{1} \mathrm{H}-\mathrm{NMR}\left(\mathrm{CDCl}_{3}\right) \delta, 8.17(1 \mathrm{H}, \mathrm{d}, \mathrm{CH}, \mathrm{J}=8.2), 8.12$ $(1 \mathrm{H}, \mathrm{s}, \mathrm{CH}), 8.04(1 \mathrm{H}, \mathrm{s}, \mathrm{NH}), 7.93(1 \mathrm{H}, \mathrm{s}, \mathrm{CH}), 7.68(1 \mathrm{H}, \mathrm{s}, \mathrm{CH}), 7.59(1 \mathrm{H}, \mathrm{d}, \mathrm{CH}, \mathrm{J}=8.1)$, $7.42(2 \mathrm{H}, \mathrm{t}, \mathrm{CH}, \mathrm{J}=7.8,6.1), 4.49\left(2 \mathrm{H}, \mathrm{q}, \mathrm{CH}_{2}\right), 4.53\left(2 \mathrm{H}, \mathrm{q}, \mathrm{CH}_{2}\right), 2.90\left(2 \mathrm{H}, \mathrm{s}, \mathrm{CH}_{2}\right), 1.29(3 \mathrm{H}$, t, $\left.\mathrm{CH}_{3}, \mathrm{~J}=8.8,1.9\right), 1.21\left(3 \mathrm{H}, \mathrm{t}, \mathrm{CH}_{3}, \mathrm{~J}=7.1,1.8\right) .{ }^{13} \mathrm{C}-\mathrm{NMR}\left(\mathrm{CDCl}_{3}\right) \delta 14.4,15.3,32,37.6$, 70.5, 104, 106, 108, 110, 112, 117, 119, 121, 121.7, 125, 126, 127, 135, 162, 168, 187. MS: [m/z] $348(22 \%, M)$. Anal. calcd./found for $\mathrm{C}_{21} \mathrm{H}_{20} \mathrm{~N}_{2} \mathrm{O}_{3}$ : C, 72.40/72.36; H, 5.79/5.76; N, 8.04/ 8.06 .

7. Yield, $60 \%$, m.p. $72-73{ }^{\circ} \mathrm{C}$. IR $(\mathrm{KBr}) \mathrm{cm}^{-1} 1665$ [C=O], 1710 [C=O], 1180 [C-N str], 860 [omonosub]. ${ }^{1} \mathrm{H}-\mathrm{NMR}\left(\mathrm{CDCl}_{3}\right) \delta, 8.0(1 \mathrm{H}, \mathrm{s}, \mathrm{NH}), 7.74(1 \mathrm{H}, \mathrm{s}, \mathrm{CH}), 7.70(1 \mathrm{H}, \mathrm{s}, \mathrm{CH}), 7.55(1 \mathrm{H}$, $\mathrm{d}, \mathrm{CH}, \mathrm{J}=7.2), 7.40(1 \mathrm{H}, \mathrm{d}, \mathrm{CH}, \mathrm{J}=8.2), 7.30(2 \mathrm{H}, \mathrm{d}, \mathrm{CH}, \mathrm{J}=7.5), 7.21(2 \mathrm{H}, \mathrm{t}, \mathrm{CH}, \mathrm{J}=7.1$, 1.8), $7.14(1 \mathrm{H}, \mathrm{t}, \mathrm{CH}, \mathrm{J}=7.5,1.7), 7.08(1 \mathrm{H}, \mathrm{t}, \mathrm{CH}, \mathrm{J}=7.5,1.8), 7.00(1 \mathrm{H}, \mathrm{t}, \mathrm{CH}, \mathrm{J}=7.1,6.2)$, $3.89\left(2 \mathrm{H}, \mathrm{q}, \mathrm{CH}_{2}\right), 2.90\left(2 \mathrm{H}, \mathrm{s}, \mathrm{CH}_{2}\right), 1.51\left(3 \mathrm{H}, \mathrm{t}, \mathrm{CH}_{3}, \mathrm{~J}=7.6,6.8\right) .{ }^{13} \mathrm{C}-\mathrm{NMR}\left(\mathrm{CDCl}_{3}\right) \delta 14$, $28,37.8,104,108,112,119,119.8,121,122,125,127,128,128.6,129,135,136,138,139$, 168, 187. MS: [m/z] $380\left(18 \%, \mathrm{M}^{+}\right)$. Anal. calcd./found for $\mathrm{C}_{25} \mathrm{H}_{20} \mathrm{~N}_{2} \mathrm{O}_{2}: \mathrm{C}, 78.93 / 78.91 ; \mathrm{H}$, 5.30/5.28; N, 7.36/7.40.

8. Yield, 57\%, m.p. $190-191{ }^{\circ} \mathrm{C}$. IR $(\mathrm{KBr}) \mathrm{cm}^{-1} 3600[\mathrm{O}-\mathrm{H}], 1665[\mathrm{C}=\mathrm{O}], 1680[\mathrm{C}=\mathrm{O}$ in pyrimidinone ring]. ${ }^{1} \mathrm{H}-\mathrm{NMR}\left(\mathrm{CDCl}_{3}\right) \delta, 8.17(1 \mathrm{H}, \mathrm{s}, \mathrm{CH}), 8.17(1 \mathrm{H}, \mathrm{d}, \mathrm{CH}, \mathrm{J}=8.8), 8.02(1 \mathrm{H}$, s, CH), $8.0(1 \mathrm{H}, \mathrm{s}, \mathrm{NH}), 7.59(1 \mathrm{H}, \mathrm{d}, \mathrm{CH}, \mathrm{J}=8.3), 7.42(2 \mathrm{H}, \mathrm{t}, \mathrm{CH}, \mathrm{J}=8.8,6.5), 6.00(1 \mathrm{H}, \mathrm{s}$, $\mathrm{CH}), 4.53\left(2 \mathrm{H}, \mathrm{q}, \mathrm{CH}_{2}\right), 2.90\left(2 \mathrm{H}, \mathrm{s}, \mathrm{CH}_{2}\right), 2.43\left(3 \mathrm{H}, \mathrm{s}, \mathrm{CH}_{3}\right), 2.0(2 \mathrm{H}, \mathrm{s}, \mathrm{NH}$ and $\mathrm{OH}), 1.29(3 \mathrm{H}$, $\left.\mathrm{t}, \mathrm{CH}_{3} \mathrm{~J}=8.1,6.5\right) .{ }^{13} \mathrm{C}-\mathrm{NMR}\left(\mathrm{CDCl}_{3}\right) \delta 14,18,28,37,96,108,103,110,111,114,120,121.7$, 125, 126, 134, 137, 150, 153, 156, 164.6. MS: [m/z] 392 (11\%, M). Anal. calcd./found for $\mathrm{C}_{21} \mathrm{H}_{20} \mathrm{~N}_{4} \mathrm{O}_{2} \mathrm{~S}: \mathrm{C}, 64.27 / 64.22 ; \mathrm{H}, 5.14 / 5.12 ; \mathrm{N}, 14.28 / 14.24 ; \mathrm{S}, 8.17 / 8.21$.

9. Yield, 56\%, m.p. $210-212{ }^{\circ} \mathrm{C}$. IR $(\mathrm{KBr}) \mathrm{cm}^{-1} 2212[\mathrm{~S}-\mathrm{H}], 1665[\mathrm{C}=\mathrm{O}], 1680[\mathrm{C}=\mathrm{O}$ in pyrimidinone ring]. ${ }^{1} \mathrm{H}-\mathrm{NMR}\left(\mathrm{CDCl}_{3}\right) \delta, 8.17(1 \mathrm{H}, \mathrm{s}, \mathrm{CH}), 8.17(1 \mathrm{H}, \mathrm{d}, \mathrm{CH}), 8.02(1 \mathrm{H}, \mathrm{s}, \mathrm{CH})$, $8.0(1 \mathrm{H}, \mathrm{s}, \mathrm{NH}), 7.59(1 \mathrm{H}, \mathrm{d}, \mathrm{CH}, \mathrm{J}=8.3), 7.42(2 \mathrm{H}, \mathrm{t}, \mathrm{CH}, \mathrm{J}=8.8,6.5), 5.33(1 \mathrm{H}, \mathrm{s}, \mathrm{CH}), 4.53$ $\left(2 \mathrm{H}, \mathrm{q}, \mathrm{CH}_{2}\right), 2.90\left(2 \mathrm{H}, \mathrm{s}, \mathrm{CH}_{2}\right), 2.43\left(3 \mathrm{H}, \mathrm{s}, \mathrm{CH}_{3}\right), 2.0(1 \mathrm{H}, \mathrm{s}, \mathrm{NH}), 1.5(1 \mathrm{H}, \mathrm{s}, \mathrm{SH}), 1.29(3 \mathrm{H}, \mathrm{t}$, $\left.\mathrm{CH}_{3}, \mathrm{~J}=8.1,6.5\right) .{ }^{13} \mathrm{C}-\mathrm{NMR}\left(\mathrm{CDCl}_{3}\right) \delta 14.2,18.1,27.5,40.3,86.3,108,103.3,110,111.8,114$, 120, 121.7, 125, 126, 134.5, 137, 150, 153, 156, 164.6. MS: [m/z] 408 (17\%, M). Anal. calcd./found for $\mathrm{C}_{21} \mathrm{H}_{20} \mathrm{~N}_{4} \mathrm{OS}_{2}$ : C, 61.74/61.71; H, 4.93/4.95; N, 13.75/13.71; S, 15.70/15.63.

10. Yield, 59\%, m.p. $121-122^{\circ} \mathrm{C}$. IR $(\mathrm{KBr}) \mathrm{cm}^{-1} 1665$ [C=O], 1581 [C=N str], 1242 [C-N str]. ${ }^{1} \mathrm{H}-\mathrm{NMR}\left(\mathrm{CDCl}_{3}\right) \delta, 8.14(1 \mathrm{H}, \mathrm{s}, \mathrm{CH}), 8.0(1 \mathrm{H}, \mathrm{s}, \mathrm{NH}), 7.61(1 \mathrm{H}, \mathrm{s}, \mathrm{CH}), 7.55(1 \mathrm{H}, \mathrm{d}, \mathrm{CH}, \mathrm{J}=$ 8.7), $7.40(1 \mathrm{H}, \mathrm{d}, \mathrm{CH}, \mathrm{J}=8.8), 7.37(1 \mathrm{H}, \mathrm{s}, \mathrm{CH}), 7.08(1 \mathrm{H}, \mathrm{t}, \mathrm{CH}, \mathrm{J}=8.0,6.4), 7.00(1 \mathrm{H}, \mathrm{t}, \mathrm{CH}$, $\mathrm{J}=8.5,6.7), 3.89\left(2 \mathrm{H}, \mathrm{q}, \mathrm{CH}_{2}\right), 3.49\left(2 \mathrm{H}, \mathrm{s}, \mathrm{CH}_{2}\right), 2.35\left(3 \mathrm{H}, \mathrm{s}, \mathrm{CH}_{3}\right), 1.51\left(3 \mathrm{H}, \mathrm{t}, \mathrm{CH}_{3}, \mathrm{~J}=8.7\right.$, 6.2). ${ }^{13} \mathrm{C}-\mathrm{NMR}\left(\mathrm{CDCl}_{3}\right) \delta 14,24,37,44,103,106,108,109,110,111,118,119,121,125,126$, 127, 132, 157, 158, 164, 168. MS: [m/z] $342\left(12 \%, \mathrm{M}^{+}\right)$. Anal. calcd./found for $\mathrm{C}_{21} \mathrm{H}_{18} \mathrm{~N}_{4} \mathrm{O}: \mathrm{C}$, 73.67/73.63; H, 5.30/5.32; N, 16.36/16.40.

11. Yield, $61 \%$, m.p. $165-167^{\circ} \mathrm{C}$. IR $(\mathrm{KBr}) \mathrm{cm}^{-1} 1665$ [C=O], 1580 [C=N str], 1210 [C-N str]. ${ }^{1} \mathrm{H}-\mathrm{NMR}\left(\mathrm{CDCl}_{3}\right) \delta, 8.0(1 \mathrm{H}, \mathrm{s}, \mathrm{NH}), 7.98(1 \mathrm{H}, \mathrm{s}, \mathrm{CH}), 7.61(1 \mathrm{H}, \mathrm{s}, \mathrm{CH}), 7.55(1 \mathrm{H}, \mathrm{d}, \mathrm{CH})$, $7.40(1 \mathrm{H}, \mathrm{d}, \mathrm{CH}, \mathrm{J}=8.7), 7.37(1 \mathrm{H}, \mathrm{s}, \mathrm{CH}), 7.08(1 \mathrm{H}, \mathrm{t}, \mathrm{CH}), 7.00(1 \mathrm{H}, \mathrm{t}, \mathrm{CH}, \mathrm{J}=8.0,6.4), 4.0$ $\left(2 \mathrm{H}, \mathrm{s}, \mathrm{NH}_{2}\right), 3.89\left(2 \mathrm{H}, \mathrm{q}, \mathrm{CH}_{2}\right), 3.49\left(2 \mathrm{H}, \mathrm{s}, \mathrm{CH}_{2}\right), 1.51\left(3 \mathrm{H}, \mathrm{t}, \mathrm{CH}_{3}, \mathrm{~J}=8.7,6.2\right) .{ }^{13} \mathrm{C}-\mathrm{NMR}$ $\left(\mathrm{CDCl}_{3}\right) \delta 14.6,24.8,37,40.3,44,103.5,106,108,109,110,111,118,119,121.7,124,126.2$, 127, 132.5, 157.8, 158, 164, 168.9. MS: [m/z] $343(14 \%, M)$. Anal. calcd./found for $\mathrm{C}_{20} \mathrm{H}_{17} \mathrm{~N}_{5} \mathrm{O}$ : 
C, 69.96/ 69.94; H, 4.99/4.97; N, 20.40/20.42.

12. Yields, $58 \%$, m.p. $175-177{ }^{\circ} \mathrm{C}$. IR $(\mathrm{KBr}) \mathrm{cm}^{-1} 1660$ [C=O], 980 [C-O-N str.], 3510 [O-H]. ${ }^{1} \mathrm{H}-\mathrm{NMR}\left(\mathrm{CDCl}_{3}\right) \delta, 8.17(1 \mathrm{H}, \mathrm{d}, \mathrm{CH}, \mathrm{J}=8.9), 8.11(1 \mathrm{H}, \mathrm{s}, \mathrm{CH}), 8.02(1 \mathrm{H}, \mathrm{s}, \mathrm{CH}), 8.0(1 \mathrm{H}, \mathrm{s}$, $\mathrm{NH}), 7.82(1 \mathrm{H}, \mathrm{s}, \mathrm{CH}), 7.59(1 \mathrm{H}, \mathrm{d}, \mathrm{CH}, \mathrm{J}=8.2), 7.42(2 \mathrm{H}, \mathrm{t}, \mathrm{CH}, \mathrm{J}=7.7,6.0), 6.90(1 \mathrm{H}, \mathrm{s}$, $\left.\mathrm{NH}_{2}\right), 4.53\left(2 \mathrm{H}, \mathrm{q}, \mathrm{CH}_{2}\right), 4.4(1 \mathrm{H}, \mathrm{s}, \mathrm{CH}), 4.0(1 \mathrm{H}, \mathrm{s}, \mathrm{NH}), 3.49\left(2 \mathrm{H}, \mathrm{s}, \mathrm{CH}_{2}\right), 2.0(2 \mathrm{H}, \mathrm{s}, \mathrm{OH})$, $1.29\left(3 \mathrm{H}, \mathrm{t}, \mathrm{CH}_{3}, \mathrm{~J}=8.7,6.2\right) .{ }^{13} \mathrm{C}-\mathrm{NMR}\left(\mathrm{CDCl}_{3}\right) \delta 14,37,40,44,99,102,103,109,110$, $111.2,112,120.9,121,122.7,125,126.2,136,138,160,164,168.2 \mathrm{MS}:[\mathrm{m} / \mathrm{z}] 412(19 \%, \mathrm{M})$. Anal. calcd./found for $\mathrm{C}_{23} \mathrm{H}_{20} \mathrm{~N}_{6} \mathrm{O}_{2}$ : C, 66.98/66.67; H, 4.89/4.87; N,20.38/20.27.

13. Yields, 53\%, m.p. $182-184{ }^{\circ} \mathrm{C}$. IR $(\mathrm{KBr}) \mathrm{cm}^{-1} 1650[\mathrm{C}=\mathrm{O}], 1573[\mathrm{C}=\mathrm{N}$ str], 725 [C-S str]. ${ }^{1} \mathrm{H}-\mathrm{NMR}\left(\mathrm{CDCl}_{3}\right) \delta 8.17(1 \mathrm{H}, \mathrm{d}, \mathrm{CH}, \mathrm{J}=8.9), 8.11(1 \mathrm{H}, \mathrm{s}, \mathrm{CH}), 8.02(1 \mathrm{H}, \mathrm{s}, \mathrm{CH}), 8.0(1 \mathrm{H}, \mathrm{s}$, $\mathrm{NH}), 7.82(1 \mathrm{H}, \mathrm{s}, \mathrm{CH}), 7.59(1 \mathrm{H}, \mathrm{d}, \mathrm{CH}, \mathrm{J}=8.2), 7.42(2 \mathrm{H}, \mathrm{t}, \mathrm{CH}, \mathrm{J}=7.7,6.0), 6.90(1 \mathrm{H}, \mathrm{s}$, $\left.\mathrm{NH}_{2}\right), 4.53\left(2 \mathrm{H}, \mathrm{q}, \mathrm{CH}_{2}\right), 3.7(1 \mathrm{H}, \mathrm{s}, \mathrm{CH}), 4.0(1 \mathrm{H}, \mathrm{s}, \mathrm{NH}), 3.49\left(2 \mathrm{H}, \mathrm{s}, \mathrm{CH}_{2}\right), 1.5(1 \mathrm{H}, \mathrm{s}, \mathrm{SH})$, $1.29\left(3 \mathrm{H}, \mathrm{t}, \mathrm{CH}_{3}, \mathrm{~J}=8.7,6.2\right) .{ }^{13} \mathrm{C}-\mathrm{NMR}\left(\mathrm{CDCl}_{3}\right) \delta 14,37,40,44,99,102,103,109,110$, $111.2,112,120.9,121,122.7,125,126.2,136,138,160,164,168.2$. MS: [m/z] $428(11 \%, \mathrm{M})$. Anal. calcd./found for $\mathrm{C}_{23} \mathrm{H}_{20} \mathrm{~N}_{6} \mathrm{OS}$ : C, 64.47/64.50; H, 4.70/4.72; N,19.61/19.64; S, 7.48/7.44.

14. Yield, $62 \%$, m.p. $90-91{ }^{\circ} \mathrm{C}$. IR (KBr) cm 3550 [O-H], $1670[\mathrm{C}=\mathrm{O}] .{ }^{1} \mathrm{H}-\mathrm{NMR}\left(\mathrm{CDCl}_{3}\right) \delta$ $8.17(1 \mathrm{H}, \mathrm{d}, \mathrm{CH}, \mathrm{J}=7.7), 8.11(1 \mathrm{H}, \mathrm{s}, \mathrm{CH}), 8.02(1 \mathrm{H}, \mathrm{s}, \mathrm{CH}), 8.0(1 \mathrm{H}, \mathrm{s}, \mathrm{NH}), 7.71(2 \mathrm{H}, \mathrm{d}, \mathrm{CH}$, $\mathrm{J}=7.9), 7.59(1 \mathrm{H}, \mathrm{d}, \mathrm{CH}, \mathrm{J}=8.1), 7.42(2 \mathrm{H}, \mathrm{t}, \mathrm{CH}, \mathrm{J}=7.2,5.9), 7.40(2 \mathrm{H}, \mathrm{t}, \mathrm{CH}, \mathrm{J}=7.1,6.3)$, $7.33(1 \mathrm{H}, \mathrm{t}, \mathrm{CH}, \mathrm{J}=7.2,6.5), 6.00(1 \mathrm{H}, \mathrm{s}, \mathrm{CH}), 4.53\left(2 \mathrm{H}, \mathrm{q}, \mathrm{CH}_{2}\right), 2.90\left(2 \mathrm{H}, \mathrm{s}, \mathrm{CH}_{2}\right), 2.0(2 \mathrm{H}, \mathrm{s}$, $\mathrm{NH}$ and $\mathrm{OH}), 1.29\left(3 \mathrm{H}, \mathrm{t}, \mathrm{CH}_{3}, \mathrm{~J}=7.7,6.2\right) .{ }^{13} \mathrm{C}-\mathrm{NMR}\left(\mathrm{CDCl}_{3}\right) \delta 14,40.3,42.1,97,103.3,104$, 109.7, 110, 111, 119, 121, 125, 126, 127, 128, 129.2, 129.5, 132.5, 133.0, 138, 153, 158, 164, 168.2.MS: [m/z] $422(12 \%, M)$. Anal. calcd./found for $\mathrm{C}_{26} \mathrm{H}_{22} \mathrm{~N}_{4} \mathrm{O}_{2}: \mathrm{C}, 73.92 / 73.88 ; \mathrm{H}$, 5.25/5.22; N,13.26/13.30.

15. Yield, 57\%, m.p. $117-119{ }^{\circ} \mathrm{C}$. IR $(\mathrm{KBr}) \mathrm{cm}^{-1} 2180$ [S-H], 1680 [C=O], 810 [C-S str]. ${ }^{1} \mathrm{H}-$ NMR $\left(\mathrm{CDCl}_{3}\right) \delta, 8.17(1 \mathrm{H}, \mathrm{d}, \mathrm{CH}, \mathrm{J}=7.7), 8.17(1 \mathrm{H}, \mathrm{s}, \mathrm{CH}), 8.02(1 \mathrm{H}, \mathrm{s}, \mathrm{CH}), 8.0(1 \mathrm{H}, \mathrm{s}, \mathrm{NH})$, $7.71(2 \mathrm{H}, \mathrm{d}, \mathrm{CH}, \mathrm{J}=7.9), 7.59(1 \mathrm{H}, \mathrm{d}, \mathrm{CH}, \mathrm{J}=8.1), 7.42(2 \mathrm{H}, \mathrm{t}, \mathrm{CH}, \mathrm{J}=7.2,5.9), 7.40(2 \mathrm{H}, \mathrm{t}$, $\mathrm{CH}, \mathrm{J}=7.1,6.3), 7.33(1 \mathrm{H}, \mathrm{t}, \mathrm{CH}, \mathrm{J}=7.2,6.5), 5.33(1 \mathrm{H}, \mathrm{s}, \mathrm{CH}), 4.53\left(2 \mathrm{H}, \mathrm{q}, \mathrm{CH}_{2}\right), 2.90(2 \mathrm{H}, \mathrm{s}$, $\left.\mathrm{CH}_{2}\right), 2.0(1 \mathrm{H}, \mathrm{s}, \mathrm{NH}), 1.5(1 \mathrm{H}, \mathrm{s}, \mathrm{SH}), 1.29\left(3 \mathrm{H}, \mathrm{t}, \mathrm{CH}_{3}, \mathrm{~J}=7.7,6.2\right) .{ }^{13} \mathrm{C}-\mathrm{NMR}\left(\mathrm{CDCl}_{3}\right) \delta 14$, 40.3, 42.1, 97, 103.3, 104, 109.7, 110, 111, 119, 121, 125, 126, 127, 128, 129.2, 129.5, 132.5, 133.0, 138, 153, 158, 164, 168.2.MS: [m/z] $438(20 \%, M)$. Anal. calcd./found for $\mathrm{C}_{26} \mathrm{H}_{22} \mathrm{~N}_{4} \mathrm{OS}$ : C, $71.21 / 71.25 ; \mathrm{H}, 5.06 / 5.11 ; \mathrm{N}, 12.78 / 12.74$.

Comparative analysis between conventional and microwave synthesis revealed us that microwave process allows access to a library of pyrimidine annulated analogues of carbazolo fused azepinones in very short reaction time without affecting the yield and purity of the target compounds (Table 1).

Table 1 . Showing the difference between conventionally and microwave assisted reactions.

\begin{tabular}{|c|c|c|c|c|}
\hline Compound & Time conventionally (h) & Yield (\%) & Time microwave assisted (min) & Yield (\%) \\
\hline $\mathbf{8}$ & $13-14$ & 57 & 13 & 44 \\
\hline $\mathbf{9}$ & $13-14$ & 56 & 13 & 49 \\
\hline $\mathbf{1 0}$ & 42 & 59 & 10 & 63 \\
\hline $\mathbf{1 1}$ & 56 & 61 & 10 & 65 \\
\hline $\mathbf{1 2}$ & $22-24$ & 58 & 16 & 52 \\
\hline $\mathbf{1 3}$ & $23-24$ & 53 & 16 & 49 \\
\hline
\end{tabular}

Preliminary acute toxicity studies revealed that test compounds were safe and did not cause any mortality up to a maximum dose of $1000 \mathrm{mg} / \mathrm{kg}$ body weight. The animals were physically 
active and were consuming food and water in a regular way. But, few behavioral changes were observed in mice at higher doses in the response to test compounds like altered alertness, touch response, and locomotion. Therefore, 1/100th of the maximum tolerated dose, i.e. $10 \mathrm{mg} / \mathrm{kg}$ body weight (b.w.) was chosen for the studies.

The abdominal constriction response induced by glacial acetic acid is a sensitive procedure to establish peripherally acting analgesics. This response is thought to involve local peritoneal receptors. Acetic acid causes inflammatory pain by inducing capillary permeability and liberating endogenous substances that excite pain nerve ending. Acetic acid is also known to increase $\mathrm{PGE}_{1}$ and $\mathrm{PGE}_{2}$ peripherally [19]. In acetic acid induced writhing model, all the compounds $(10 \mathrm{mg} / \mathrm{kg})$ exhibited impressive analgesic activity via reduction of writhes in mice. It is noteworthy, that compound 13 caused maximum inhibition $(80.1 \%, \mathrm{p}<0.05)$ and was comparable to standard (Table 2).

Table 2. Effect of synthesized compounds on acetic acid induced writhing in mice $(n=6)$.

\begin{tabular}{|l|c|c|}
\hline Treatment $(\mathrm{mg} / \mathrm{kg})$ & Mean number of writhes & Percentage inhibition (\%) \\
\hline Control & $63.0 \pm 12^{*}$ & $00^{* *}$ \\
\hline Aspirin $(10 \mathrm{mg} / \mathrm{kg})$ & $8.0 \pm 6.1^{*}$ & $87.3^{* *}$ \\
\hline Compound $\mathbf{1 2}(10 \mathrm{mg} / \mathrm{kg})$ & $18.8 \pm 1.4^{*}$ & $69.8^{* *}$ \\
\hline Compound $\mathbf{1 3}(10 \mathrm{mg} / \mathrm{kg})$ & $12.3 \pm 2.6^{*}$ & $80.1^{* *}$ \\
\hline Compound $\mathbf{1 4}(10 \mathrm{mg} / \mathrm{kg})$ & $46.8 \pm 3.2^{*}$ & $25.5^{* *}$ \\
\hline Compound $\mathbf{1 5}(10 \mathrm{mg} / \mathrm{kg})$ & $24.5 \pm 2.9^{*}$ & $57.7^{* *}$ \\
\hline
\end{tabular}

Each value represents mean \pm SEM. ${ }^{*} \mathrm{p}<0.05$ compared with control (student's t-test) $n=6$ ). ${ }^{* *} p<0.001$.

NSAIDs can inhibit COX in peripheral tissues and therefore interfere with the mechanism of transduction of primary afferent nociceptors [20]. The mechanism of analgesic activity of compounds could be probably due to the blockade of the effect or the release of endogenous substances that excite pain nerve endings similar to that of aspirin and NSAIDs. Thus, the reduction in the number of writhing by the test compounds indicates that compounds might exert analgesic activity by inhibition of liberating endogenous substances like prostaglandin and other cytokines that excite pain nerve ending and induces pain or via inhibition of arachidonic acid pathway or their key enzymes like cyclooxygenases. Thus results obtained in this study indicate that test compounds possess analgesic properties probably via peripheral inhibitory mechanisms.

\section{CONCLUSION}

In summary, several elegant protocols have been developed to provide an easy access to the novel pyrimido annulated analogues of carbazolo condensed azepinone derivatives (8-15) from the corresponding oxoketenedithioacetal, 2 -(dimethylaminomethylene) ketone, $\beta$-oxo-enolether and $\alpha, \beta$-unsaturated ketones $(4,5,6$ and 7$)$, respectively, in high yield and purity. Among all test compounds, compound $\mathbf{1 3}$ displayed most profound analgesic effect and found comparable to standard. Further studies in depth toxicity studies and PK-PD studies could to be helpful in designing a more potent analgesic for therapeutic use in the field of medical science.

\section{ACKNOWLEDGEMENTS}

Authors are grateful to the Director CDRI, Lucknow (India) for providing the spectral data of the compounds and thankful to Department of Science and Technology (DST), New Delhi (India) for providing financial assistance to (Banasthali Centre for Education and Research in Basic Sciences) under their CURIE programme. 


\section{REFERENCES}

1. Mulwad, V.V.; Patel, C.A. Synthesis of some anti-microbial heterocycles from pyrano-tetra hydro carbazole. Ind. J. Chem. 2005, 44B, 2355-2361.

2. Kunick, C.; Link, A. Synthesis of pyrido[3,4-d]benzazepines. J. Heterocycl. Chem. 1995, 32, 803-805.

3. Patel, M.R.; Akbari, J.D.; Purohit, D.H. Synthesis and evaluation of pharmacological activity of some new aminopyrimidine and thiopyrimidine derivatives. J. Indian Chem. Soc. 2007, 84, 1169-1173.

4. Sun, C.M.; Lin, L.G.; Yu, H.J.; Cheng, C.Y.; Tsai, Y.C.; Chu, C.W.; Din, Y.H.; Chau, Y.P.; Don, M.J. Synthesis and cytotoxic activities of 4,5-diarylisoxazoles. Bioorg. Med. Chem. lett. 2007, 17, 1078-1081.

5. Kohfeld, S.; Jones, P.G.; Totzke, F.; 1-Aryl-4,6-dihydropyrazolo[4,3- $d][1]$ benzazepin5(1H)-ones: A new class of antiproliferative agents with selectivity for human leukemia and breast cancer cell lines. Eur. J. Med. Chem. 2007, 42, 1317-1324.

6. Xie, X.; Lemcke, T.; Gussio, R.; Zaharevitz, D.W.; Leost, M.; Meijer, L.; Kunick, C.; Epoxide-containing side chains enhance antiproliferative activity of paullones. Eur. J. Med. Chem. 2005, 40, 655-661.

7. Holla, S.B.; Mahalinga, M.; Karthikeyan, S.M.; Akberali, M.P.; Shetty, S.N. Synthesis of some novel pyrazolo[3,4- $d]$ pyrimidine derivatives as potential antimicrobial agents. Bioorg. Med. Chem. 2006, 14, 2040-2047.

8. Carvalho, A.M.; Esperanca, S.; Esteves, T.; Proenca, F.M. An efficient synthesis of 7,8dihydropyrimido[5,4-d]pyrimidines. Eur. J. Org. Chem. 2007, 8, 1324-1331.

9. (a) Agarwal, A.; Srivastava, K.; Puri, S.K.; Chauhan, M.S. Antimalarial activity of 2,4,6-trisubstituted pyrimidines. Bioorg. Med. Chem. Lett. 2005, 25, 1881-1883. (b) Ajibade, P.A.; Kolawole G.A. Synthesis, characterization, antiplasmodial and antitrypanosomal activity of some metal(III) complexes of sulfadiazine. Bull. Chem. Soc. Ethiop. 2008, 22, 261-268.

10. Venkatesan, K.; Satyanarayana, V.S.V.; Sivakumar, A.; Synthesis of pyrimidine carboxamide derivatives catalyzed by uranyl nitrate hexahydrate with their antibacterial and antioxidant studies. Bull. Chem. Soc. Ethiop. 2016, 30, 119-128.

11. Evans, B.E.; Rittle, K.E.; Bock, M.G.; DiPardo R.M.; Freidinger, R.M.; Whitter, W.L.; Lundell, G.F.; Veber, D.F.; Anderson, P.S.R.; Chang, S.L.; Lotti, V.J.; Cerino, D.J.; Chen, T.B.; Kling, P.J.; Kunkel, K.A.; Springer, J.P.; Hirshfieldt, J. Methods for drug discovery: development of potent, selective, orally effective cholecystokinin antagonists. J. Med. Chem. 1988, 31, 2235-2246.

12. Tseng, A.; Arthur, R.; Profile D.M.; Profile of etravirine for the treatment of HIV infection. Ther. Clin. Risk. Manag. 2010, 6, 49-58.

13. Ecobichon, D.J. Fixed Dose Procedure, Guideline 420, The Basis of Toxicity Testing, 2nd ed., CRC Press: Boca Raton; 1997; p 43.

14. Koster, R.; Anderson, M.; De Beer, E.J. Acetic acid for analgesic screening. Fed. Proc. 1959, 18, 412-418.

15. Agrawal, M.; Jain, S.; Dwivedi, J.; Kishore, D. Application of novel precursors derived from carbazolo condensed azepinones to the direct single step synthesis of corresponding isoxazole and pyrazole annulated analogues of medicinal importance. OPEM, 2012, 12, 141150.

16. (a) Jain, S.; Sharma, A.; Agrawal, M.; Sharma, S.; Dwivedi, J.; Kishore, D. Synthesis and antimicrobial evaluation of some novel trisubstituted s-triazine derivatives based on isatinimino, sulphonamido and azacarbazole. J. Chem. 2012, 2012, 131-136. (b) Suresh, R.; Sakthinathan, S.P; Kamalakkannan, D; Ranganathan, K.; Sathiyamoorthi, K.; Solvent-free synthesis of azomethines, spectral correlations and antimicrobial activities of some Ebenzylidene-4-chlorobenzenamines. Bull. Chem. Soc. Ethiop. 2015, 29, 275-290 
17. Devi, K.; Asmat, Y.; Agrawal, M.; Sharma, S.; Dwivedi, J. Synthesis and evaluation of some novel precursors of oxazolidinone analogues of chloroquinoline for their antimicrobial and cytotoxic potential. J. Chem. Sci. 2013, 125, 1093-1110.

18. (a) Gupta, R.R. Heterocyclic Chemistry II: Five-Membered Heterocycles, Springer Verlag: Berlin; 2005. (b) Roers, C.U.; Corson, B.B. Synthesis of tetrahydrocarbazole by JappKlingemann reaction. Org. Synth. Coll. 1964, 4, 884.

19. Kumar, V.; Singh, P.N.; Bhattacharya, S.K. Anti-inflammatory and analgesic activity of Indian Hypericum perforatum L. Indian J. Exp. Biol. 2001, 19, 339-343.

20. Adzu, B.; Amos, S.; Kapo, S.D.; Gamaniel, K.S. Anti-inflammatory and anti-nociceptive effects of Sphaeranthus senegalensis. J. Ethnopharmacol. 2003, 84, 169-173. 